\title{
Między fundamentalizmem a relatywizmem. 0 praktycznych i teoretycznych konsekwencjach detotalizacji współczesnej polityki
}

\section{Between Fundamentalism and Relativism. On the Practical and Theoretical Consequences of the Detotalization of Contemporary Politics}

\begin{abstract}
The author assumes that nowadays one can talk about the crisis of a realistic paradigm in the contemporary political theory that seems to be related to the postmodernist detotalization of modern politics. The aim of the article is to point out and discuss some of the theoretical and practical consequences of this fact, which the author mainly connetcs with the redefinition of the concept of the political. Referring to the theory of modernity of Ágnes Heller and Ferenc Fehér, he discusses both the negative consequences of this phenomenon, which is associated with the escalation of fundamentalist and relativistic attitudes, and the concept of political hermeneutics, understood as a kind of antidote to previously signaled problems.
\end{abstract}

Keywords: detotalization, hermeneutics, postmodernity, the concepts of the political, relativism, fundamentalism

Wydaje się, że w ostatnim ćwierćwieczu minionego stulecia paradygmat realistyczny popadł $\mathrm{w}$ niełaskę przedstawicieli szeroko rozumianej humanistyki. $\mathrm{Z}$ jednej strony zaczęto podważać możliwości eksplanacyjne teorii realistycznych, które miałyby w zadowalający sposób wyjaśniać tajniki funkcjonowania tej wersji społeczeństwa zachodniego, jaka miała zrodzić się w dynamicznej, zmiennej i chronicznie niestabilnej rzeczywistości późnej nowoczesności. Tego rodzaju krytyka niosła ze sobą przede wszystkim oskarżenia o naiwność realistów, którzy mieli w dalszym ciągu żyć złudzeniami odnośnie do możliwości poznania/dotarcia do obiektywnie istniejącej rzeczywistości (również politycznej). 
Podkreślano, że już sama specyfika ówczesnej polityki, w sensie istniejących lub pojawiających się nieustannie nowych instytucji, podmiotów, problemów oraz praktyk społecznych, politycznych i kulturowych, przeczyła jakoby wspomnianym wyżej fundamentalnym założeniom teoretycznym realizmu. Kryzys paradygmatu realistycznego $\mathrm{w}$ refleksji nad polityką zdaje się związany $\mathrm{z}$ nabierającym rozpędu w owym czasie zjawiskiem, które na potrzeby tego szkicu określam mianem postmodernistycznej detotalizacji polityki nowoczesnej.

W prezentowanym opracowaniu chcę wskazać prawdopodobne źródła kryzysu realistycznego podejścia w naukach o polityce, których doszukuję się właśnie we wspomnianej przed chwilą detotalizacji nowoczesności. Nie jest to zatem wypowiedź, która w wyczerpujący sposób definiuje czy choćby opisuje główne założenia paradygmatu realistycznego - problem realizmu politycznego traktuję tu raczej jako domyślny punkt odniesienia snutej przeze mnie opowieści. Moje ambicje są bowiem mniejszego formatu: pragnę jedynie uchwycić moment zakwestionowania dominacji tych teorii naukowych, które - zdroworozsądkowo przecież - zakładają, że właściwe rozpoznanie rzeczywistości jest możliwe tylko wtedy, gdy za oczywisty uznamy fakt jej obiektywnego istnienia. Dodatkowo chciałbym zasygnalizować niektóre teoretyczne i praktyczne konsekwencje tego faktu, który wiążę głównie ze zjawiskiem redefinicji pojęcia polityczności. W swych rozważaniach inspiruję się analizami tego fenomenu, które można odnaleźć w licznych pracach Âgnes Heller i Ferenca Fehéra.

Szkic dzielę na pięć części. W pierwszej krótko omawiam zjawisko postmodernistycznej detotalizacji nowoczesności. W części drugiej i trzeciej koncentruję swą uwagę na erozji tradycyjnego rozumienia pojęcia polityczności, stanowiącej efekt oddziaływania wspomnianych wcześniej procesów detotalizacyjnych. W części czwartej próbuję pokazać negatywne konsekwencje tego fenomenu, które dostrzegam w eskalacji postaw fundamentalistycznych i/lub relatywistycznych, zaś w piątej - ostatniej - mówię o hermeneutyce politycznej jako antidotum na sygnalizowane już bolączki ponowoczesności.

\section{Detotalizacja polityki}

Pojęciem detotalizacji, które do słownika współczesnej humanistyki wprowadził Jean-François Lyotard, posługuję się zgodnie z tym znaczeniem, jakie nadała mu Ágnes Heller (Heller, 2012, s. 125-145). Zgodnie z jej wykładnią detotalizacja to ogólne określenie dla tych procesów społecznych, politycznych i kulturowych, które w ciągu ostatnich kilku dekad XX wieku doprowadziły do fragmentaryzacji - rozbicia, rozczłonkowania - kolejnych sfer społeczeństw nowoczesnych. Jako że pisałem o tym już w innym miejscu (Bulira, 2018, s. 336-369), pozwolę sobie 
ograniczyć swe wyjaśnienia do dość ogólnego stwierdzenia, że fenomen detotalizacji polega na odrzuceniu uniwersalistycznego i holistycznego sposobu postrzegania rzeczywistości ludzkiej. Detotalizacja stanowi zatem nie tylko oczywiste przeciwieństwo skłonności do totalizacji (ujednolicania, traktowania jako spójną całość) rzeczywistości, która cechowała typowo modernistyczny sposób patrzenia na uniwersum spraw (nie tylko) społeczno-politycznych, lecz także staje w opozycji do nowego zjawiska, będącego paradoksalnym rezultatem samej detotalizacji - do tego problemu powrócę jeszcze $w$ dalszych partiach artykułu - tj. do retotalizacji.

I chociaż Heller wymienia aż pięć głównych form (płaszczyzn) detotalizacji, to wydaje się, że w interesującym mnie kontekście najważniejsze są dwie z nich: detotalizacja historii oraz detotalizacja pojęcia prawdy ${ }^{1}$. Jeśli chodzi o tę pierwszą, to oznacza ona wieszczone przez Lyotarda odrzucenie tzw. wielkich narracji, czyli tego sposobu rozumienia historii, który - jak wyjaśnia z kolei Ferenc Fehér - bezpośrednio nawiązywał do „heglowskiej koncepcji »historii uniwersalnej «", znoszącej „wszelkie partykularne opowieści, oferując w zamian historię zunifikowaną" (Fehér, 2013, s. 174). Detotalizacja historii oznacza więc rezygnację z patrzenia na dzieje w kategoriach teleologicznych. Historia, z domeny, którą rządzi konieczność, staje się tym samym sferą, której rytm funkcjonowania dyktuje wszechobecna kontyngencja. Konsekwencje takiej zmiany myślenia o historii są bardzo istotne, ponieważ pozbawiona wpisanego w nią celu nie tylko staje się ona dziełem konkretnych ludzi (a nie jakiejś zewnętrznej względem nich siły: Boga/Ducha/natury/obiektywnych praw logiki/konieczności itp.), lecz także na znaczeniu zyskuje ten jej moment, który dla twórców wielkich narracji miał znaczenie niewielkie: teraźniejszość. Wielkie opowieści traktowały teraźniejszość jako konieczny - z reguły przykry i kłopotliwy - etap przejściowy, który należy pokonać po to, by w końcu osiągnąć to, co czeka na nas w przyszłości.

Detotalizacja historii niesie ze sobą uznanie teraźniejszości za najważniejszy jej (historii) moment, a taka zmiana rozłożenia akcentów ma ogromne znaczenie dla rzeczywistości społeczno-politycznej. Oznacza, że dla współczesnych uczestników polityki liczą się przede wszystkim działania ukierunkowane na te konkretne problemy i bolączki nowoczesności, których rozwiązanie może poprawić aktualną sytuację. Liczy się więc to, co tu i teraz. W wyniku detotalizacji horyzont czasowy celów, skutków i poczucia odpowiedzialności za podejmowane działania skurczył się zatem w sposób zasadniczy.

$\mathrm{Z}$ kolei detotalizacja pojęcia prawdy $\mathrm{w}$ praktyce oznacza postulat odrzucenia koncepcji prawdy uniwersalnej i absolutnej, co jest konsekwencją tego, że nowo-

W eseju Co to jest „postmodernizm”? - ćwierć wieku później mowa jest dodatkowo o: detotalizacji form życia, detotalizacji sztuk oraz „postmodernistycznej dekompozycji muzeów”. Zob. Heller, 2012, s. 125-145. 
czesność, tak jak rozumie ją Heller, jest epoką, w której dokonała się uniwersalizacja wartości wolności. Jej uniwersalny charakter oznacza z jednej strony, że dotyczy ona wszystkich mieszkańców nowoczesności, z drugiej zaś, że jako taka jest ona pozbawiona treści substancjalnej - ma charakter formalny. Treść substancjalna jest jej nadawana poprzez jej konkretyzację, czyli drogą interpretacji. W tym miejscu dochodzimy do problemu, który Heller określa mianem paradoksu wolności: wolność może być (i jest) interpretowana na różne sposoby, co z kolei sprawia, że nie ma ona jednej, ostatecznej treści, dlatego też poszczególne koncepcje wolności rywalizują ze sobą o miano tej właściwej konkretyzacji wolności (Heller, 2012, s. 117). Tego rodzaju pluralizm interpretacyjny wartości wolności generuje swoisty chaos aksjologiczny, co z kolei skazuje mieszkańców nowoczesności na życie w świecie pozbawionym pewności. I chociaż poszukują oni trwałego oparcia dla swej egzystencji, czegoś w rodzaju nienaruszalnego, „absolutnego” fundamentu - w dalszym ciągu poszukują i potrzebują więc prawdy - to jednak mają świadomość tego, że w ich świecie nie ma już miejsca dla tradycyjnie rozumianego absolutu. Takich absolutów, tak jak prawd oraz interpretacji wolności, może być po prostu wiele.

\section{Redefinicja pojęcia polityczności}

Jakie konsekwencje zasygnalizowane powyżej procesy detotalizacyjne przyniosły dla sfery polityki (po)nowoczesnej? Znaczne, zarówno w sferze porządkujących/wyjaśniających ją teorii, jak i zachodzących w niej praktyk. Zacznijmy od tej drugiej kwestii. W tym przypadku wypada przede wszystkim zauważyć, że detotalizacja oznaczała odrzucenie nie tylko dotychczas dominujących, modernistycznych form działań politycznych, lecz także samego sposobu rozumienia polityki, który można by określić mianem holistycznego. Polityka, widać to wyraźnie na przykładzie ujmowania jej w kategoriach klasowych, była bowiem dotąd zarezerwowana dla tych podmiotów zbiorowych - zazwyczaj masowych partii politycznych - które realizowały interesy określonych, wyraźnie wyodrębnionych i, co ważniejsze, świadomych własnej odrębności klas społecznych. Takie zawężenie listy potencjalnych uczestników polityki (głównych graczy) determinowało jednocześnie jej zakres przedmiotowy: za polityczne uznawano te zagadnienia, których realizacja służyła interesom antagonistycznie nastawionych do siebie klas społecznych. Do tak urządzonej przestrzeni politycznej, która, powtórzmy, została zagospodarowana przez podmioty kolektywne, traktowane tu jako byty realnie istniejące, jednostka, wraz z całym bagażem własnych doświadczeń, potrzeb i celów, miała dostęp jedynie pośredni.

Detotalizacja rozumianej w kategoriach modernistycznych, „silnie zakodowanej" (Heller, Fehér, 1991) sfery polityki zmieniła ją w dwojaki sposób: posze- 
rzyła się ona w sensie podmiotowym (ilościowym) oraz przedmiotowym (jakościowym). Innymi słowy, polityka zdetotalizowana otworzyła się zarówno na nowe problemy, jak i na nowych uczestników. W języku praktyki politycznej zmianę tę dokumentują na przykład działania tzw. nowych ruchów społecznych, które, jak się wydaje, na dobre już wpisały się w krajobraz ponowoczesnej sceny politycznej (Offe, 1995; Touraine, 1995; Bulira, 2017). Ruchy te wkraczają na ponowoczesną agorę $\mathrm{z}$ hasłami rozwiązania konkretnego problemu społecznego, ekonomicznego czy też kulturowego. Jako takie, mimo że stają się aktywnymi i pełnoprawnymi uczestnikami życia politycznego, nie oferują pełnego i spójnego programu politycznego, czy nawet określonego światopoglądu, ani też - co wydaje się naturalną konsekwencją takiego stanu rzeczy - nie identyfikują się z jakąś określoną klasą społeczną, której interesy miałyby reprezentować. Przeciwnie, racją ich istnienia jest właśnie to, że podnoszą one te zagadnienia/problemy, którymi nie zajmują się tradycyjne partie polityczne, bo albo ich po prostu nie dostrzegają, albo też nie mieszczą się one w ich orbicie zainteresowań (ich zakres wykracza poza wąsko rozumiany tu interes danej grupy). Innymi słowy, nowe ruchy społeczne upolityczniają zagadnienia, które dotąd politycznymi nie były (Fehér, Heller, 1989, s. 3).

Zdetotalizowana sfera polityki otworzyła (poszerzyła) się także w sensie przedmiotowym (jakościowym). W praktyce fenomen ten oznacza przede wszystkim rzeczywistą redefinicję pojęcia polityczności. Postmodernistyczna detotalizacja polityki nowoczesnej, w pewnym sensie przygotowana przez poststrukturalistów, by wspomnieć jedynie prace Michela Foucaulta, ukazała złudność wiary $\mathrm{w}$ to, że świat nowoczesny posiada wpisaną w siebie nieusuwalną, sztywną strukturę. Wskazanie i opisanie takiej struktury w przypadku polityki - na przykład wspomniane wcześniej postrzeganie polityki jako sfery, w której toczy się walka pomiędzy klasami - umożliwiało zrozumienie zachodzących w niej procesów politycznych, dzięki czemu ona sama (sfera polityki) stawała się przejrzysta i uporządkowana. Detotalizacja polityki położyła kres takiemu postrzeganiu polityki, która tym samym okazywała się otwarta na różne problemy.

Zjawisko przedmiotowego poszerzenia polityki współczesnej wiąże się więc $\mathrm{z}$ redefinicją pojęcia polityczności, która polega przede wszystkim na zniesieniu sztywnych kryteriów umożliwiających określenie tego, co polityczne (Heller, 2005). W konsekwencji mamy do czynienia $z$ otwarciem się sfery polityki na te kwestie, które wcześniej się w niej nie znajdowały, a wokół których obecnie toczy się (lub potencjalnie może się toczyć) dyskusja i gra polityczna. Ich dotychczasowa nieobecność w debacie publicznej, a nade wszystko fakt ich ignorowania ze strony uczestników polityki instytucjonalnej (partii politycznych) brały się głównie stąd, że zwyczajnie odmawiano im charakteru politycznego. Niepolityczność takich zagadnień, jak na przykład stan środowiska naturalnego, pra- 
wa zwierząt, prawa mniejszości seksualnych czy etnicznych/rasowych, wynikała zaś stąd, że nie mieściły się one w obszarze zainteresowań tradycyjnych uczestników świata polityki, czyli - pozostańmy na gruncie teorii walki klas - nie miały przykładowo charakteru klasowego. Po prostu ze swej „natury” nie były one polityczne. Wynika stąd, że strukturalne rozumienie i praktykowanie polityki, które przypisywało niezmienny charakter temu, co polityczne, zakładało istnienie jakiejś prawdziwej rzeczywistości politycznej. Jej wyraźnie określony charakter miał kluczowe znaczenia zarówno w stosunku do podmiotów uczestniczących w polityce, jak i zagadnień (treści), które brały one pod uwagę.

\section{Realizm czy konstruktywizm?}

Teoretyczne konsekwencje zwrotu postmodernistycznego ukazują swe pełne oblicze zwłaszcza wtedy, gdy przywołamy kategorię realizmu politycznego. Jeśli posłużyć się ukutą na potrzeby tej wypowiedzi - roboczą, bardzo ogólną - definicją owego stanowiska, jako takiego, które zakłada istnienie jakiejś obiektywnej rzeczywistości politycznej, w której uczestniczą aktorzy polityczni i którą, właśnie dzięki temu, że jest ona choćby względnie stabilna (stała), bo z reguły utrwalona określonymi założeniami metafizycznymi, można w sposób właściwy opisaćl poznać, to transformacja sfery polityki zachodnich społeczeństw nowoczesnych, jaka dokonała się w ostatnim ćwierćwieczu minionego stulecia, podważa słuszność diagnoz czynionych w ramach tego paradygmatu. Już samo zadomowienie się (na stałe?) nowych ruchów społecznych w ponowoczesnej sferze publicznej zdaje się świadczyć przede wszystkim o tym, że obiektywna rzeczywistość polityczna, która miałaby rzekomo rządzić się wpisanymi w nią równie obiektywnymi - choć możliwymi do poznania - prawami, nie istnieje, a przynajmniej: że nic nie wskazuje na to, iż mamy do niej pewny i bezpośredni dostęp².

Podstawowy kłopot $\mathrm{z}$ bezkrytyczną akceptacją postulatu zwolenników realizmu politycznego, aby odnosić się do istniejącej po prostu rzeczywistości politycznej, zamieszkanej przez byty polityczne, których charakter polityczny można określić na przykład dzięki zastosowaniu odpowiednich kryteriów tego, co polityczne, wziął się stąd, że narodziny ponowoczesnej kondycji politycznej uwypukliły skrajnie niestabilny, płynny i zaskakująco plastyczny charakter tej rzeczywistości. Praktyka społeczno-polityczna, jaką możemy na co dzień obserwować

W jednym z pierwszych rodzimych opracowań podejścia konstruktywistycznego Andrzej Zybertowicz argumentował, że zwolennicy konstruktywizmu społecznego nie tyle kwestionują istnienie takiej rzeczywistości (obiektywnej), ile wątpią w prawomocność roszczeń tych badaczy, którzy deklarują niezapośredniczony dostęp do niej. Zob. Zybertowicz, 1995, 2006. 
w społeczeństwach zachodnich, wskazuje na to, że rzeczywistość polityczna jest raczej konstruowana niż odkrywana, a zatem wszystko, co w niej zachodzi, a także reguły, które nią rządzą, mają charakter konwencjonalny. Wbrew klasycznym - realistycznym - wykładniom pojęcia polityczności, które możemy odnaleźć w pracach wybitnych postaci nowożytnej i współczesnej zachodniej myśli politycznej, to, co polityczne, nie ma stałej i - raz jeszcze nadużyję tego określenia - obiektywnej treści. I nie chodzi nawet o to, że nie miał racji Machiavelli, kiedy powiadał, iż o wyjątkowości sfery polityki przesądza to, że działania w niej podejmowane mają być skuteczne, ani też - że pozwolę sobie na daleki skok czasowy do pierwszej połowy XX wieku - Carl Schmitt, gdy deklarował, że zjawiska polityczne odznaczają się tym, iż zmuszają nas do czynienia dystynkcji pomiędzy wrogami i przyjaciółmi. Chodzi tu raczej o to, że w realiach społeczeństwa (po)nowoczesnego żadne $\mathrm{z}$ tak jednostronnych i arbitralnych podejść nie wyczerpuje sensu/treści tego, co polityczne. Okazuje się bowiem, że w ponowoczesności mogą one zgodnie koegzystować ze sobą. Alternatywa „albo to istnieje, albo tamto istnieje” została bowiem wyparta przez koniunkcję „, i to istnieje, $\mathbf{i}$ to istnieje”.

Treść ponowoczesnego rozumienia pojęcia polityczności jest otwarta i jako taka znajduje się w ciągłym „ruchu”, co z kolei zdaje się świadczyć nie tylko o tym, że rzeczywistość społeczno-polityczna jest konstrukcją, lecz także o tym, że jako taka podlega ona stałym, niekończącym się renegocjacjom. Zjawisko upolityczniania kolejnych problemów przez różnego rodzaju podmioty indywidualne lub zbiorowe, to znaczy inicjowania wokół nich debaty publicznej po to, by właściwe instytucje podjęły próbę ich rozwiązania dzięki podjęciu odpowiednich decyzji politycznych i prawnych, jest już dla nas czymś normalnym. Tak jak i coraz mniej dziwi nas katalog owych problemów trafiających na wokandę opinii publicznej, który wydaje się niczym nieograniczony. Czy nam się to podoba, czy nie, w ponowoczesnej nowoczesności polityczne okazuje się to, co zostaje po prostu upolitycznione. Warunkiem koniecznym i zarazem wystarczającym do upolitycznienia danej kwestii jest jedynie wzbudzenie zainteresowania opinii publicznej określonym problemem. Zwróćmy uwagę, że tak pojmowana (i praktykowana) polityczność pozbawiona jest więc treści substancjalnej, której precyzyjne określenie było podstawowym celem autorów takich jak Carl Schmitt czy choćby Hannah Arendt, w swych dziełach sugestywnie opłakująca śmierć „prawdziwej polityki”. To nowe rozumienie polityczności ma charakter formalny. A zatem tak jak tradycyjnie rozumiane pojęcie polityczności wykluczało, ponieważ albo zakładało istnienie wyraźnie wyznaczonej sfery, po wkroczeniu do której dane zjawisko/działanie/rzecz nabierało charakteru politycznego, albo też wskazywało na niezbywalne cechy określonej grupy fenomenów, które przesądzały o tym, że były one polityczne, tak ponowoczesne rozumienie tego, co polityczne, staje się bardziej egalitarne i inkluzywne. 


\section{Relatywizm i fundamentalizm}

Zarazem proceder stałego/cyklicznego redefiniowania pojęcia polityczności generuje wiele istotnych problemów, z których na pierwszy plan wysuwają się dwa poważne zagrożenia dla stabilności czy wręcz przetrwania świata nowoczesnego: relatywizm i fundamentalizm. Paradoksalnie, oba te zjawiska mają jedno źródło: swymi korzeniami tkwią w bezrefleksyjnej akceptacji słynnej dewizy Paula Feyerabenda, zgodnie z którą w naszym świecie wszystko ujdzie (anything goes). Jako takie jawią się więc one jako efekt postępującej detotalizacji nowoczesności. Wszak to detotalizacja podważyła wiarę w uniwersalne oraz obiektywne standardy, reguły czy normy jednostkowego i wspólnotowego funkcjonowania w świecie, w którym głównym punktem odniesienia jest wolność - podobnie jak i samo pojęcie polityczności - pozbawiona konkretnej treści. Jej formalny charakter sprawia, że z założenia niczego nie można z niej wykluczyć: anything goes. Tak rozumiana wolność (po)nowoczesna jest przykładem opisywanego swego czasu przez Jacques’a Derridę pharmakonu: jest zarazem lekarstwem i trucizną.

O konsekwencjach bezrefleksyjnej akceptacji generowanej przez procesy detotalizacyjne kategorii różnicy (aksjomat postmodernizmu) pisali wielokroć Heller i Fehér, powiadając, że prowadzi ona do relatywizmu. Zarazem, co warte podkreślenia, w tym przypadku chodziło im nie tyle o „relatywizm” wynikający z faktu odrzucenia przez kulturę ponowoczesną takich pojęć, jak: Historia, Prawda czy Sztuka. Obawiali się oni raczej tego, że procesy detotalizacyjne mogą pójść nieco za daleko i niechęć do tego, co uniwersalne, przerodzi się w niechęć do jakiejkolwiek formy absolutu - również tego, który ma ograniczony (historycznie, kulturowo) charakter. W tym też sensie ostrzegali oni przed relatywizmem, rozumianym przez nich jako stanowisko głoszące niemożność jakiejkolwiek formy wartościowania i oceniania. Ich obawy dotyczyły więc tego, aby zjawisko pluralizacji kolejnych sfer rzeczywistości (po)nowoczesnej nie zamieniło się w bezkrytyczne uwielbienie pustej znaczeniowo kategorii różnicy, a postmodernistyczna detotalizacja i bliźniacza dla niej dekonstrukcja nie przerodziły się w destrukcję wszelkich światów życia i konstytuujących je systemów wartości. Wolność, która staje się celem samym w sobie, to znaczy taka, która nie zna żadnych ograniczeń (zobowiązań, powinności i odpowiedzialności), może bowiem szybko przerodzić się w niewolę.

Te negatywne konsekwencje bezrefleksyjnej akceptacji (absolutyzacji) różnicy, w wyniku których realny staje się problem utraty jakichkolwiek trwałych fundamentów funkcjonowania jednostki/wspólnoty w świecie wypełnionym kontyngencją, generuje często postawy fundamentalistyczne. Fundamentalizm, jak sama nazwa wskazuje, jest postawą, w ramach której podejmuje się działania zmierzające do odzyskania utraconego, nienaruszalnego fundamentu. Funda- 
mentalizm redukuje złożoność świata, w którym funkcjonuje fundamentalista. Dla Heller i Fehéra przykładem tej postawy są różnego rodzaju ruchy biopolityczne, których zwolennicy interpretują wszystkie problemy współczesnego świata wyłącznie przez pryzmat interesującego ich zagadnienia (Fehér, Heller, 1994; Heller, 2014; Bulira, 2014). Takie jednostronne rozumienie rzeczywistości siłą rzeczy zniekształca ją - kreśli jej wypaczony obraz. Na bazie tej atrakcyjnej, bo kusząco prostej (uproszczonej), wizji świata rodzi się często bliskie fundamentalizmowi poczucie funkcjonowania w oblężonej twierdzy, w której zwolennicy tej czy innej ideologii trwają niezłomnie jako strażnicy Dobra i Prawdy. W tym przypadku paradoksem jest jednak to, że ich działania wpisują się w paradygmat konstruktywistyczny: obiektywny i uniwersalny charakter odtworzonego fundamentu (rzeczywistości) okazuje się wszak konwencjonalny.

\section{Hermeneutyka polityczna}

Poddana detotalizacji polityka (po)nowoczesna ma zatem janusowe oblicze. $\mathrm{Z}$ jednej strony otwiera się zarówno na nowe problemy, jak i nowych uczestników oraz nowe formy działań politycznych, co świadczy o tym, że ma w sobie ogromny potencjał emancypacyjny. $Z$ drugiej jednak strony te nowe możliwości - wolność qua przygodność - same z siebie niczego nie gwarantują. Pojawia się bowiem pytanie o to, która wartość/forma/cel działania jest właściwa? Wielość możliwości może wywoływać poczucie zagubienia, które często, jeśli ten stan utrzymuje się przez dłuższy czas, przeradza się w strach przed kontyngencją, a ten zaś może rodzić postawy fundamentalistyczne. Lektura prac Heller i Fehéra $z$ lat 90. XX wieku, czyli z okresu, kiedy ambiwalencji ponowoczesnej kondycji politycznej posmakowali w końcu również mieszkańcy państw byłego bloku wschodniego, nie pozostawia złudzeń, że to właśnie tym kwestiom węgierscy myśliciele poświęcali wiele miejsca.

Oprócz diagnozy i charakterystyki problemu szukają oni także wyjścia $\mathrm{z}$ tej patowej sytuacji. Powiadają, że rzeczywistości, z założenia wieloznacznej, niedookreślonej, ambiwalentnej i płynnej, nie można narzucić sztywnych i ostatecznych ram teoretycznych, które starają się uchwycić jakąś wpisaną w nią stałą strukturę i porządek. Dlatego ratunku budapeszteńczycy szukają w tradycji hermeneutycznej: zamiast teorii realistycznej proponują więc teorię polityki, która swój potencjał eksplanacyjny czerpie z interpretacji. Zwłaszcza Fehér uporczywie powraca do idei takiego sposobu uprawiania i rozumienia polityki, który określa właśnie mianem hermeneutycznego. W eseju Hermeneutic as Europe’s Mainstream Political Tradition charakteryzuje hermeneutykę polityczną (określaną też przez niego niekiedy mianem „hermeneutycznej kultury politycznej”). 
Powiada zatem, że tego rodzaju postawa polityczna (i związany z nią określony rodzaj wyobraźni politycznej) zakłada, iż w życiu społecznym (politycznym, kulturowym) jest miejsce na wiele prawd - ograniczanie tej przestrzeni do wyłącznie jednej prawdy ma charakter arbitralny i nieuprawniony. Albo jeszcze inaczej: nawet jeśli w życiu społecznym (jak i politycznym czy kulturowym) jest miejsce na jedną prawdę, za którą opowiadają się członkowie tego społeczeństwa, nie oznacza to zarazem, że obowiązuje ich wyłącznie jedna jej interpretacja. W świecie (kulturze) zbudowanym na fundamencie wolności wydaje się to po prostu niemożliwe, by nie powiedzieć nawet - nienaturalne. Jest tak dlatego, że w języku społeczno-politycznym dominacja jednej interpretacji lub jednego źródła sensów i znaczeń spraw społecznych oznacza po prostu narzucenie (pod groźbą użycia przemocy fizycznej w przypadku niedostosowania się) określonym grupom społecznym, klasom czy mniejszościom odgórnie (arbitralnie) dobranego systemu wartości, bądź też wskazanie konkretnych miejsc i funkcji w strukturze społecznej, jakie winni oni pełnić. Oczywiste zaś jest, że tego rodzaju proceder niesie ze sobą wyraźne ograniczenie wolności owych mniejszości (grup, klas...). Zwolennicy hermeneutyki politycznej opowiadają się więc po stronie pluralizmu i różnorodności. Klimat intelektualny panujący obecnie w świecie zachodniej (po)nowoczesności nie tylko uprawomocnia istnienie wielu interpretacji jednego tekstu, ale też stwarza odpowiednie warunki do uznania wielości tekstów, które mogą podlegać takim interpretacjom (Fehér, 1989, s. 81). W świecie zachodnim trwa w najlepsze proces rozpoznawania kolejnych tekstów, które mają mieć znaczenie fundamentalne dla jego mieszkańców.

Chociaż Fehér zdaje się traktować hermeneutykę polityczną jako swego rodzaju fundament polityczny świata (po)nowoczesnego, to konstatując permanentny kryzys tego świata (lub może lepiej wypadałoby powiedzieć: dostrzegając czyhające nań liczne i nieustannie powracające, bo nieusuwalnie weń wpisane, niebezpieczeństwa), diagnozuje jednocześnie zjawiska i procesy destabilizujące samą hermeneutyczną kulturę polityczną. Zgodnie z przyjętą perspektywą wspomniane już wcześniej zagrożenie relatywizmem jest konsekwencją swoistego kulturowego bogactwa urodzaju (wielości tekstów oraz mnogości ich interpretacji) i polega na tym, że ów nadmiar tekstów oraz ich interpretacji wprowadza w życiu jednostkowym i społecznym chaos aksjologiczny, polityczny, moralny. Oznacza bowiem przede wszystkim utratę stałych i pewnych, bo wyraźnie określonych i głęboko zakorzenionych w danej tradycji, punktów orientacyjnych, dzięki którym jednostce (społeczeństwu) łatwiej oceniać i działać. W przypadku zaś, gdy do miana takich drogowskazów rości sobie prawo zbyt wiele równie ważnych tekstów (czyli np. systemów wartości, ideologii i reprezentujących je partii politycznych, modeli - utopii - harmonijnego życia społecznego etc.), okazuje się, że skuteczna orientacja jest niezwykle trudna lub nawet zwyczajnie 
niemożliwa. Jednoznaczny i ostateczny wybór jednego - właściwego - punktu odniesienia jest praktycznie niemożliwy w tym sensie, że dokonującemu wyboru takiego punktu odniesienia brakuje... odpowiedniego punktu odniesienia, dzięki któremu ten konkretny wybór mógłby zostać uzasadniony i oceniony, choćby nawet przez samego wybierającego, jako trafny.

Fehér, nawiązując implicite do ustaleń Hansa-Georga Gadamera, powiada, że interpretacjami nieuprawnionymi będą nie te, które źle ujmują obiektywnie istniejącą rzeczywistość (polityczną), lecz te, które wykraczają poza (lub w ogóle ich nie uwzględniają) wspólnotowe, historyczno-kulturowe uwarunkowania/ ograniczenia perspektywy tego, kto dokonuje interpretacji, oraz poza okoliczności, w jakich powstał sam tekst. W podobny sposób, choć może nieco bardziej radykalnie, wypowiada się zresztą amerykański teoretyk literatury Stanley Fish, który prawomocności interpretacji doszukuje się w oczywistym dla niego fakcie jej zakorzenienia w czymś, co określa mianem wspólnoty interpretacyjnej. Jeśli można w ogóle mówić o dowolności interpretacji - zdaje się sugerować amerykański autor - to tylko w ograniczonym sensie: owe interpretacje, o ile oczywiście domagają się uznania ich prawomocności, muszą uwzględniać bowiem te sensy, znaczenia, język w ogóle, które są wspólne członkom danej społeczności/wspólnoty/kultury. Nie może być przecież mowy o jakiejkolwiek komunikacji w chwili, gdy strony w niej uczestniczące nie dzielą ze sobą czegoś wspólnego. W tym właśnie sensie można powiedzieć, że o ile dana interpretacja odwołuje się do wartości/ sensów/znaczeń rozpoznanych przez określoną wspólnotę interpretacyjną, z którą identyfikuje się dany interpretator, o tyle będzie ona mogła słusznie - i skutecznie - domagać się uznania. Poprawna interpretacja jawi się tu zatem jako forma czytania danego tekstu za pomocą narzędzi powszechnie akceptowanych i stosowanych przez członków danej wspólnoty (Fish, 2002).

W tym kontekście pojawia się oczywiście problem natury zasadniczej: na jakiej podstawie (w odniesieniu do jakich wartości) rozstrzygnięcia te winny być dokonywane? Skąd właściwie wiemy, że dokonane przez nas wybory tego, a nie innego tekstu oraz takiej, a nie innej jego interpretacji są tymi właściwymi? Z lektury Hermeneutic as Europe's Mainstream Political Tradition można odnieść wrażenie, że to nie tylko sam nadmiar tekstów domagających się interpretacji ani też zwykła nadwyżka ich interpretacji martwią Fehéra, lecz właśnie niektóre sposoby radzenia sobie $\mathrm{z}$ tą bolączką hermeneutyki politycznej. Węgierski filozof wyraźnie obawia się tych wyborów - rozstrzygnięć - które dokonywane są w sposób, jak powiedzieliśmy, arbitralny. W przeważającej mierze nie odwołują się one do wartości uniwersalnych obowiązujących w świecie zachodniej nowoczesności - o niej wszak cały czas mówimy - przez co ich rezultaty okazują się nazbyt substancjalne, skrajnie jednostronne, ale i ostateczne, to znaczy takie, które roszczą sobie pretensje do miana oczywiście prawdziwych, a tym samym obiektywnych i niepodważalnych. 
Chociaż budapeszteńczycy z reguły nie szafują ostatecznymi i uniwersalnymi odpowiedziami na formułowane przez siebie pytania, to jednak $\mathrm{w}$ ramach preferowanego przez nich podejścia zazwyczaj znajduje się również miejsce na pozytywne próby rozwiązania diagnozowanych problemów. Nie inaczej jest $\mathrm{w}$ interesującym nas teraz przypadku. Aby zatem uniknąć dwóch skrajnych (i przez to niebezpiecznych) rezultatów narodzin hermeneutycznej kultury politycznej powiada Fehér - „[...] musimy dysponować takimi zasadami, które mogłyby służyć nam dwojako: zarówno jako drogowskazy dla naszego rozwoju, jak i ograniczenia dla tych tendencji, które wydają się niepożądane. Musimy dysponować przynajmniej dwiema zasadami, dzięki którym będziemy mogli nie tylko interpretować, ale i hamować nadmiar interpretacji”. Tymi zasadami - konkluduje węgierski filozof - są „nadrzędne wartości wolno ści oraz ży c i a” (Fehér, 1989, s. 91). W języku omawianej tu koncepcji hermeneutyki politycznej należy zatem powiedzieć, że na gruncie tej koncepcji dopuszczalne i wskazane są tylko takie teksty i takie ich interpretacje, które przynajmniej nie kolidują z rzeczywistą realizacją wartości wolności i życia. Obie te wartości mają charakter uniwersalny, ale, jako że wszystkie wartości są historycznie i kulturowo-politycznie usytuowane, ich normatywność jest warunkowa - ma ograniczony zasięg: spełniają swoją funkcję w ramach (realiach) świata (po)nowoczesnego.

\section{Zakończenie}

Współczesna kultura polityczna wymaga szczególnej troski zwłaszcza w obliczu zakrojonej na szeroką skalę ponowoczesnej detotalizacji głównych wartości i zjawisk świata nowoczesnego. Detotalizacja ta zaowocowała skrajnym rozbiciem - fragmentaryzacją - dyskursu publicznego zdominowanego przez liczne mikronarracje/mikrodyskursy, które samym swym istnieniem legitymizują własne... istnienie, ale i które nieustannie wchodzą ze sobą w nie zawsze przyjazne i pokojowe interakcje. Taka sytuacja jest niebezpieczna w tym sensie, że grozi utratą dotychczasowego dorobku naszego świata - stępieniem jej rzeczywiście emancypacyjnego potencjału. Wydaje się, że to właśnie w hermeneutyce politycznej, rozumianej tu przecież również jako rodzaj praktyki politycznej, można pokładać nadzieję na odrodzenie się tego, co wspólne mieszkańcom ponowoczesności zachodniej. To ona może dostarczyć ogólnych ram teoretyczno-praktycznych ponowoczesnej debacie publicznej, która, jeśli wciąż liczymy na skuteczną komunikację pomiędzy jej uczestnikami, domaga się dla nich jakiegoś wspólnego mianownika. Jest ona zatem próbą antyfundamentalistycznej, bo świadomie i otwarcie akceptującej paradoks wolności, restauracji fundamentu świata nowoczesnego. W projekcie tym udaje się pogodzić typowe dla herme- 
neutyki elementy postawy konserwatywnej z konstytutywnymi dla tradycji krytycznej postulatami emancypacji.

Prezentowaną koncepcję można postrzegać też jako przykład przewartościowania $\mathrm{w}$ ramach nauk społecznych i humanistycznych (również: teorii polityki), do jakiego doszło w ostatnich dekadach XX stulecia, w wyniku którego podejście realistyczne $w$ refleksji nad światem społecznym i politycznym zdaje się ustępować pola orędownikom interpretacjonizmu i konstruktywizmu. Propozycja Heller i Fehéra wydaje się szczególnie atrakcyjna, ponieważ jej autorzy nie chcą rezygnować $\mathrm{z}$ wartości uniwersalnych, których obecność $\mathrm{w}$ sferze polityki jest zwyczajnie niezbędna, zarazem jednak ich wysiłek intelektualny nie polega na tym, aby udowodnić „realne” istnienie tych wartości - ich teoria nie czerpie swej mocy z przyjętych założeń metafizycznych. Jest to teoria wpisująca się w horyzont ponowoczesności, a zatem jej twórcy akcentują umowny historyczny, kulturowy - charakter egzystencji wartości wolności i życia w nowoczesności. Ich uprzywilejowana pozycja jest efektem świadomej - arbitralnej - decyzji mieszkańców świata nowoczesnego.

\section{Literatura}

Bulira, W. (2014). „Biopolityka ponowoczesności: casus Ágnes Heller i Ferenca Fehéra”. Kronos, 31 (4), s. 138-153.

Bulira, W. (2017). „Nowe ruchy społeczne: nowa jakość w polityce ponowoczesnej?”. W: M. Marczewska-Rytko, D. Maj (red.). Nowe ruchy społeczne. Lublin: Wydawnictwo UMCS, s. 27-36.

Bulira, W. (2018). Teoria krytyczna szkoły budapeszteńskiej. Od totalitaryzmu do postmodernizmu. Monografie Fundacji na rzecz Nauki Polskiej. Toruń: Wydawnictwo Naukowe UMK.

Fehér, F. (1989). „Hermeneutic as Europe’s Mainstream Political Tradition”. Thesis Eleven, 22 (1), s. 79-91.

Fehér, F. (2013). „Pożegnanie z Lukácsem. Rzecz o schyłku wielkich narracji”. Przegląd Polityczny, 118, s. 174-176.

Fehér, F., Heller, Á. (1989). The Postmodern Political Condition. Cambridge-New York: Polity Press.

Fehér, F., Heller, Á. (1994). Biopolitics. Aldershot-Brookfield-Hong Kong-SingaporeSydney: Avebury.

Fish, S. (2002). Interpretacja, retoryka, polityka, przeł. K. Abriszewski [et al.]. Kraków: Universitas.

Heller, Á. (2005). „O pojęciu polityczności raz jeszcze”. Przegląd Polityczny, 69, s. $76-82$. 
Heller, Á. (2012). Eseje o nowoczesności, przeł. J.P. Hudzik et al. Toruń: Wydawnictwo Naukowe UMK.

Heller, Á. (2014). „Czy biopolityka zmieniła pojęcie polityczności?”. Kronos, 31 (4), s. $163-174$.

Heller, Á., Fehér, F. (1991). The Grandeur and Twilight of Radical Universalism. New Brunswick-London: Transaction Publishers.

Offe, C. (1995). „Nowe ruchy społeczne: przekraczanie granic polityki instytucjonalnej”. W: J. Szczupaczyński (red.). Władza i społeczeństwo. Antologia tekstów z socjologii polityki. Warszawa: Wydawnictwo Naukowe PWN, s. 226-233.

Touraine, A. (1995). „Wprowadzenie do analizy ruchów społecznych”. W: J. Szczupaczyński (red.). Władza i społeczeństwo. Antologia tekstów z socjologii polityki. Warszawa: Wydawnictwo Naukowe PWN, s. 212-225.

Zybertowicz, A. (1995). Przemoc i poznanie. Studium z nie-klasycznej socjologii wiedzy. Toruń: Wydawnictwo Naukowe UMK.

Zybertowicz, A. (2006). „Konstruktywizm jako orientacja metodologiczna w badaniach społecznych”. Czasopismo Naukowe „Kultura i Historia”. Retrieved from http://www. kulturaihistoria.umcs.lublin.pl/page/152?s (dostęp: 24.03.2013).

\section{Streszczenie}

Autor wychodzi z założenia, że obecnie można mówić o kryzysie paradygmatu realistycznego w refleksji nad polityką, który wydaje się związany z postmodernistyczną detotalizacją polityki nowoczesnej. Celem artykułu jest wskazanie i omówienie niektórych teoretycznych i praktycznych konsekwencji tego faktu, które autor wiąże przede wszystkim z redefinicją pojęcia polityczności. Nawiązując do teorii nowoczesności Ágnes Heller i Ferenca Fehéra, omawia on negatywne konsekwencje tego fenomenu, które wiąże $\mathrm{z}$ eskalacją postaw fundamentalistycznych i relatywistycznych, jak i przybliża koncepcję hermeneutyki politycznej, rozumianej jako swoiste antidotum na sygnalizowane wcześniej problemy.

Słowa kluczowe: detotalizacja, hermeneutyka, ponowoczesność, pojęcia polityczności, relatywizm, fundamentalizm 